\title{
Urgences
}

\section{Une odeur étrange...}

Évelyne Pouliot

Numéro 15, octobre 1986

Épigraphiques

URI : https://id.erudit.org/iderudit/025318ar

DOI : https://doi.org/10.7202/025318ar

Aller au sommaire du numéro

Éditeur(s)

Urgences

ISSN

0226-9554 (imprimé)

1927-3924 (numérique)

Découvrir la revue

Citer ce document

Pouliot, É. (1986). Une odeur étrange... Urgences, (15), 53-53.

https://doi.org/10.7202/025318ar

Ce document est protégé par la loi sur le droit d'auteur. L'utilisation des services d'Érudit (y compris la reproduction) est assujettie à sa politique d'utilisation que vous pouvez consulter en ligne.

https://apropos.erudit.org/fr/usagers/politique-dutilisation/
Cet article est diffusé et préservé par Érudit.

Érudit est un consortium interuniversitaire sans but lucratif composé de l’Université de Montréal, l'Université Laval et l'Université du Québec à Montréal. Il a pour mission la promotion et la valorisation de la recherche. https://www.erudit.org/fr/ 


\title{
Evelyne Pouliot
}

\author{
Le mur \\ Sur lequel ont écrit les prophètes \\ Craque... \\ King Crimson: Court of the Crimson King
}

Une odeur étrange flotte dans cet endroit

Des fissures... le long de ses murs

Et sur le bois jauni, des graffitis

Une fenêtre usée de tant de regards

Sur les bords de laquelle des traces de doigts

Une main s'agrippe

Son regard pénètre autant qu'il ne porte

$\grave{A}$ ainsi tendre les yeux

Plus loin que la marée basse et que la brume opaque...

Subsistant au temps, immuables au vent

Les idées alizées du sage au souffle marin

Il vente sur ses dires

Il tempête sur sa vie

... elle respire encore...

... elle reprend son souffle...

La vitre éclatée, fragmenté son regard

Sur la mer qui monte, se cambre et se cabre

La vague tombe

Entre la pluie sur le sol noirci

Le présent se perd dans une mare de sang

L'empreinte des doigts le souille d'autant

Des fissures élargies aux murs inexistants

La fenêtre n'est plus qu'un cadre vide au vent

Le passage agrandi du dehors au dedans

Vogue mon vague à l'âme

Vagabonde

D'ondes en rades... 